\title{
A Novel Method for Carbonate Quantification in Atmospheric Particulate Matter
}

\author{
Denise C. Napolitano ${ }^{1}$, Hilairy E. Hartnett ${ }^{1,2}$ (D) and Pierre Herckes ${ }^{1, *}$ (D) \\ 1 School of Molecular Sciences, Arizona State University, Tempe, AZ 85287-1604, USA; \\ dcnapoli@asu.edu (D.C.N.); h.hartnett@asu.edu (H.E.H.) \\ 2 School of Earth and Space Exploration, Arizona State University, Tempe, AZ 85287-6004, USA \\ * Correspondence: pierre.herckes@asu.edu
}

Received: 2 May 2020; Accepted: 12 June 2020; Published: 20 June 2020

\begin{abstract}
Inorganic carbonate can be an important component of atmospheric particulate matter in arid environments where mineral dust components contribute significantly to air particulate matter. Carbonate carbon (CC) is only rarely quantified in atmospheric studies and methods to quantify carbonate in atmospheric samples are rare. In this manuscript, we present a novel protocol for quantifying carbonate carbon in atmospheric particulate matter samples, through the acidification of aerosol filters at ambient pressure and temperature and subsequent measurement of carbon dioxide $\left(\mathrm{CO}_{2}\right)$ released upon acidification. This method is applicable to a variety of filter media used in air pollution studies, such as Teflon, cellulose, or glass fiber filters. The method allows the customization of the filter area used for analysis (up to $24 \mathrm{~cm}^{2}$ ) so that sufficient $\mathrm{CO}_{2}$ can be detected when released and to assure that the sample aliquot is representative of the whole filter. The resulting detection limits can be as low as $0.12 \mu \mathrm{g} / \mathrm{cm}^{2}$. The analysis of a known amount of sodium bicarbonate applied to a filter resulted in a relative error within $15 \%$ of the known mass of bicarbonate when measured 20 min after acidification. A particulate matter sample with aerodynamic diameter larger than $2.5 \mu \mathrm{m}\left(\mathrm{PM}_{>2.5}\right)$ collected via cascade impaction on a high-volume aerosol sampler yielded good precision, with a CC concentration of $4.4 \pm 0.3 \mu \mathrm{gC} / \mathrm{cm}^{2}$ for six replicates. The precision, accuracy, and reproducibility of this method of CC measurement make it a good alternative to existing quantification methods.
\end{abstract}

Keywords: particulate matter; air pollution; carbonate carbon; dust; coarse particulate matter; fine particulate matter

\section{Introduction}

Inorganic carbon (carbonate) is an important component of atmospheric particulate matter in arid environments. Blown dust from sources such as soils, road dust, dry lakes and construction materials is known to be a major source of particulate matter in the Phoenix area (Arizona, USA) [1-5] and elsewhere [6,7], and is a contributor to mineral dust, including carbonates, and coarse atmospheric particulate matter [8-10]. Despite its prominence, the measurement of carbonate carbon (CC) in atmospheric aerosol samples has been an ongoing challenge in the characterization of the carbonaceous components of particulate matter.

Carbonate carbon in atmospheric particulate matter is most commonly quantified using a thermal/optical carbon analyzer. Quantification methods include the analysis of evolved carbon dioxide $\left(\mathrm{CO}_{2}\right)$ from the acidification of carbonate in the instrument, the removal of $\mathrm{CO}_{2}$ before analysis by acidification, or the integration of a CC peak in the thermogram. The Desert Research Institute (DRI) Thermal/Optical Carbon Analyzer is fitted with an injection port to allow the addition of $\mathrm{HCl}$ directly to the filter under an inert atmosphere to evolve $\mathrm{CO}_{2}[11,12]$. When using this method to quantify $\mathrm{CC}$ in fine particulate matter $\left(\mathrm{PM}_{2.5}\right.$, particles with an aerodynamic diameter of less than $\left.2.5 \mu \mathrm{m}\right)$ collected 
in Xi'an (China) to determine the importance of various dust sources, differences in CC concentrations were reported to be less than $5 \%$ between replicate $0.526 \mathrm{~cm}^{2}$ quartz filter punches [13].

The other widely used commercial carbon analyzer, the Sunset Lab OCEC Aerosol Analyzer (Sunset Labs, Tigard, OR, USA), is not equipped with an injection port for in situ acidification of a sample for CC removal. A recommended method for CC quantification with this instrument is to analyze two aliquots of the same filter separately, one after exposure to $\mathrm{HCl}$ fumes and another untreated with acid [14]. In a similar approach used by other investigators, CC can be removed from aerosol samples before analysis through exposure to hydrochloric acid $(\mathrm{HCl})$ vapor to quantify only organic or elemental carbon fractions [15].

The technique of comparing acid-treated and untreated filters, however, assumes that aerosol collection on a filter is homogenous and all analyzed filter samples (with a maximum area of $1.5 \mathrm{~cm}^{2}$ ) are uniform and comparable. This is not necessarily the case for all types of aerosol samples. In fact, slotted filters, such as those used in high volume multistage impactors like the Tisch Environmental TE 235 (e.g., [16]), collect particles in narrow bands (1-2 mm wide) on the filter that make up only approximately $10 \%$ of the analyzed filter area, greatly decreasing the amount of sample that can be analyzed at once in a thermal/optical instrument. This, in addition to the coarse particle size modes collected in cascade impaction, decreases the likelihood of uniformly distributed aerosol over the filter area.

The integration of the CC peak in a thermogram is another possibility for CC quantification [17]. However, when CC is analyzed using a thermal-optical method without acidification, the evolution temperature of $\mathrm{CC}$ varies considerably, due to several factors including the mineral form of the carbonate (for example, calcite versus dolomite) and the presence of other materials in the sample matrix [18], as well as the particle size [19]. The analysis protocol also affects the evolution of CC [10]: for example, dolomite would be expected to evolve in the fourth organic carbon (OC4) fraction of the National Institute for Occupational Safety and Health (NIOSH) protocol and in the third organic carbon (OC3) fraction of the Interagency Monitoring of Protected Visual Environments (IMPROVE) protocol [11]. Additionally, the possibility of organic carbon (OC) coevolving with CC cannot be ruled out, since ambient particulate matter samples are unique to their sampling locations and times. Integration software for the Sunset Lab OCEC Aerosol Analyzer allows the opportunity to integrate a specific peak to either the thermogram baseline or to the base of the peak, but previous knowledge of the characteristics of CC and organic carbon of the sample is necessary to determine which integration method is most suitable [20]. For these reasons, CC peak integration may not be an effective method of CC quantification for all aerosol samples.

Alternative methods for CC measurements have been proposed. Carbonates in geological samples have traditionally been analyzed by acidification with concentrated phosphoric acid [21], and this process has since been adapted to measure the amount and isotopic composition of carbonates in aerosol samples [22,23]. However, this method involves the reaction of samples in vacuo, followed by the cryogenic purification of $\mathrm{CO}_{2}$, which may not be available to laboratories that do not perform routine isotopic analysis. Another method using the IR absorption of $\mathrm{CO}_{2}$ formed from acidification has been used for samples containing CC concentrations as low as $10 \mu \mathrm{g} \mathrm{CO}_{3}{ }^{2-}$ per filter [24]. In this setup, one half of a $37 \mathrm{~mm}$ filter was placed into an FTIR cell $\left(100 \mathrm{~cm}^{3}\right)$, which was evacuated, filled with vapor containing $\mathrm{HCl}$, and analyzed directly after $10 \mathrm{~min}$ (after which the IR absorbance was stable).

In this manuscript, we present an alternate method of quantifying CC in atmospheric particulate matter, through the acidification of aerosol filters at ambient pressure and temperature and subsequent measurement of the $\mathrm{CO}_{2}$ released upon acidification. This method allows the customization of the filter area used for analysis (up to $24 \mathrm{~cm}^{2}$ ) so that sufficient $\mathrm{CO}_{2}$ can be detected when released and to assure that the sample aliquot is representative of the whole filter. This method can provide a precise quantification of carbonate in aerosols regardless of sampling method, particle size, sample concentration per unit area of filter, or sample homogeneity. Additionally, since no heat 
is involved in this analysis, this method allows analysis of samples collected on filter media other than quartz, such as Teflon, cellulose, or glass fiber filters, to be analyzed for CC concentration.

\section{Experiments}

\subsection{Principle and Experimental Setup}

The principle of the analytical measurement is the determination of the amount of gaseous $\mathrm{CO}_{2}$ produced when an aerosol filter sample is acidified. The $\mathrm{CO}_{2}$ formed by acidification is used to calculate the concentration of inorganic carbon in the sample. Experiments were conducted using Nalgene jars (approximately $125 \mathrm{~mL}$ ) with a rubber septum attached to the side (Figure 1). This setup has been used to incubate soil crusts in determining nitrogen fixation activity [25] and for soil respiration rate measurements [26]. Before performing any experiments, a glass petri dish was placed in each jar, and the volumes of the incubation jars with petri dishes were measured by determining the mass of each jar, filling them to capacity with ultrapure water $(>18.2 \mathrm{M} \Omega \cdot \mathrm{cm})$, and re-measuring the mass, assuming a water density of $1 \mathrm{~g} / \mathrm{mL}$. All measurements of $\mathrm{CO}_{2}$ concentration were made using a PP Systems EGM-4 CO $\mathrm{CO}_{2}$ monitor that determines $\mathrm{CO}_{2}$ concentration (ppmv) by infrared absorbance. The instrument zero was set to ambient $\mathrm{CO}_{2}$ pressure before each measurement.
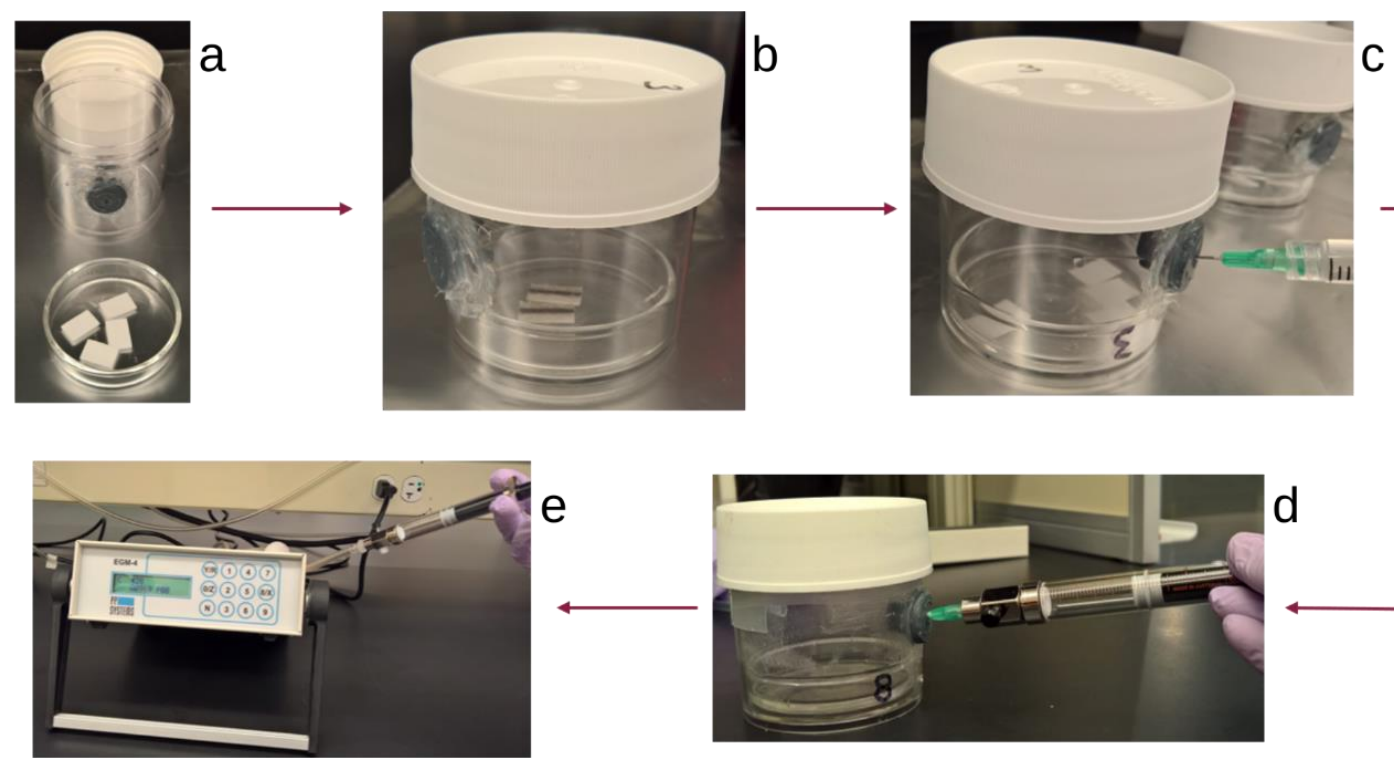

Figure 1. Flow diagram depicting the acidification of atmospheric particulate matter samples and subsequent measurement of $\mathrm{CO}_{2}$. (a) A Nalgene jar with a septum attached to the side is used for the experiment. Filter punches, each with an area of $1.5 \mathrm{~cm}^{2}$, are placed in a glass petri dish. (b) The petri dish is placed in the jar, and the jar is sealed. (c) Acid is added to the jar via syringe. (d) A gas-tight syringe is used to sample the air inside of the jar. (e) The concentration of $\mathrm{CO}_{2}$ is measured with a PP Systems EGM-4 $\mathrm{CO}_{2}$ monitor.

To perform this CC quantification method, a bicarbonate standard or aerosol sample was placed onto the petri dish inside of an incubation jar, and the jar was closed firmly (Figure 1a,b). The concentration of $\mathrm{CO}_{2}$ inside of the jar was measured by using a gas-tight syringe to remove $5 \mathrm{~mL}$ of air that was then injected into the $\mathrm{CO}_{2}$ monitor. The maximum stable $\mathrm{CO}_{2}$ concentration after injection was recorded. One molar hydrochloric acid was then added dropwise to the samples via syringe (Figure 1c), and when the reaction was complete, the air inside of the jar was sampled again for $\mathrm{CO}_{2}$ concentration (Figure $1 \mathrm{~d}$ ). The difference in concentration before and after the reaction was used to calculate the inorganic carbon associated with the sample (details are provided in SI). Ambient temperature and pressure were recorded at the start of each experiment. At the conclusion of 
each experiment, the $\mathrm{pH}$ of the liquid inside the container was measured to ensure that an excess of acid was used.

\subsection{Optimization of Experimental Parameters}

Before performing measurements of the carbonate concentration on atmospheric particulate matter samples, several components of the setup needed to be tested to ensure the integrity of the method. First, each jar was tested to ensure that the seals around the lid and septa were adequate. Then, the optimum time for the carbonate to react with $1 \mathrm{M}$ hydrochloric acid (referred to hereafter as the incubation time) was developed. Finally, the volume of acid to be used in each experiment was determined.

For all method development tests, a mixture of sodium chloride ( $\mathrm{NaCl}$, crystal, $99 \%$, Mallinckrodt Chemicals, Bedminster, NJ, USA) and sodium bicarbonate $\left(\mathrm{NaHCO}_{3}\right.$, $\mathrm{ACS}$ Reagent, $99.7-100.3 \%$, Sigma Aldrich, St. Louis, MO, USA) was prepared by homogenizing $5.2655 \mathrm{~g}$ of $\mathrm{NaCl}$ and $0.0391 \mathrm{~g}$ of $\mathrm{NaHCO}_{3}$ using a mortar and pestle, resulting in a powder of $0.51 \mathrm{~mol} \% / 0.74$ mass $\%$ of $\mathrm{NaHCO}_{3}$. This sodium bicarbonate mixture was used in all tests to optimize the experimental conditions.

\subsubsection{Incubation Jar Seal Test}

It was critical to select incubation jars that were adequately sealed from ambient conditions because ambient $\mathrm{CO}_{2}$ concentrations are substantial when compared to rather low amounts of $\mathrm{CO}_{2}$ evolving from minute $(\mu \mathrm{g})$ amounts of carbonate. This verification/selection step would apply to any kind of incubation jars for analysis of small concentrations. Among the most likely causes of a poor seal would be an ill-fitting lid; since lids were not specifically assigned to incubation jars, eleven jars and lids were randomly selected and paired. Once the volumes of the jars were determined, approximately 4-15 mg of the 0.74 mass $\% \mathrm{NaHCO}_{3}$ standard mixture was added to the petri dish placed inside of each jar. The background $\mathrm{CO}_{2}$ concentration was measured, and $1 \mathrm{M} \mathrm{HCl}$ was added to each jar. The jars were gently swirled to ensure that all of the solid came into contact with the acid and that any bubbles of $\mathrm{CO}_{2}$ gas were released from within the aqueous phase. Three measurements of $\mathrm{CO}_{2}$ were made in $5 \mathrm{~min}$ increments and a fourth was made after $2 \mathrm{~h}$ (Table 1 ). 
Table 1. Experiments performed on eleven containers to determine those that were most suitable for $\mathrm{CO}_{2}$ pressure measurements.

\begin{tabular}{|c|c|c|c|c|c|c|c|c|c|c|c|c|c|c|c|c|c|c|}
\hline \multirow[b]{2}{*}{ Jar } & \multicolumn{6}{|c|}{ Incubation Conditions } & \multicolumn{3}{|c|}{ 5-Minute Incubation } & \multicolumn{3}{|c|}{ 10-Minute Incubation } & \multicolumn{3}{|c|}{ 15-Minute Incubation } & \multicolumn{3}{|c|}{ 2-Hour Incubation } \\
\hline & $\begin{array}{l}\text { Pres. } \\
\text { (atm) }\end{array}$ & $\begin{array}{c}\text { Temp. } \\
\text { (K) }\end{array}$ & $\begin{array}{l}\text { Amount } \\
\text { of } \\
\mathrm{NaHCO}^{-} \\
\left(\times 10^{-7} \mathrm{~m}\right.\end{array}$ & $\begin{array}{l}\text { Vol. } \\
\text { (mL) } \\
\text { ool) }\end{array}$ & $\begin{array}{l}\text { Bkgrd } \\
\mathrm{CO}_{2} \\
\text { Conc. } \\
\text { (ppmv) }\end{array}$ & $\begin{array}{c}\mathrm{HCl} \\
\text { Added } \\
(\mathrm{mL})\end{array}$ & $\begin{array}{l}\mathrm{CO}_{2} \\
\text { Conc. } \\
\text { (ppmv) }\end{array}$ & $\begin{array}{l}\text { Moles } \\
\mathrm{CO}_{2} \\
\text { Formed } \\
\left(\times 10^{-7} \mathrm{~mol}\right)\end{array}$ & $\begin{array}{c}\text { Rel. } \\
\text { Error } \\
(\%)\end{array}$ & $\begin{array}{l}\mathrm{CO}_{2} \\
\text { Conc. } \\
\text { (ppmv) }\end{array}$ & $\begin{array}{l}\text { Moles } \\
\mathrm{CO}_{2} \\
\text { Formed } \\
\left(\times 10^{-7} \mathrm{~mol}\right)\end{array}$ & $\begin{array}{c}\text { Rel. } \\
\text { Error } \\
(\%)\end{array}$ & $\begin{array}{l}\mathrm{CO}_{2} \\
\text { Conc. } \\
\text { (ppmv) }\end{array}$ & $\begin{array}{l}\text { Moles } \\
\mathrm{CO}_{2} \\
\text { Formed } \\
\left(\times 10^{-7} \mathrm{~mol}\right)\end{array}$ & $\begin{array}{c}\text { Rel. } \\
\text { Error } \\
(\%)\end{array}$ & $\begin{array}{l}\mathrm{CO}_{2} \\
\text { Conc. } \\
\text { (ppmv) }\end{array}$ & $\begin{array}{l}\text { Moles } \\
\mathrm{CO}_{2} \\
\text { Formed } \\
\left(\times 10^{-7} \mathrm{~mol}\right)\end{array}$ & $\begin{array}{c}\text { Rel. } \\
\text { Error } \\
(\%)\end{array}$ \\
\hline A & 0.989 & 294.4 & 12.51 & 179.8 & 524 & 2.8 & 645 & 8.666 & -30.72 & 643 & 8.527 & -31.83 & 644 & 8.594 & -31.29 & 652 & 9.121 & -27.08 \\
\hline B & 0.989 & 294.4 & 3.700 & 175.4 & 474 & 2.6 & 515 & 2.864 & -22.59 & 515 & 2.864 & -22.59 & 514 & 2.798 & -24.37 & 514 & 2.798 & -24.37 \\
\hline $\mathrm{C}$ & 0.989 & 294.4 & 9.073 & 177.1 & 500 & 2.2 & 596 & 6.769 & -25.39 & 596 & 6.769 & -25.39 & 596 & 6.769 & -25.39 & 584 & 5.991 & -33.96 \\
\hline $\mathrm{D}$ & 0.989 & 294.4 & 6.342 & 178.3 & 471 & 2.6 & 528 & 4.049 & -36.16 & 529 & 4.118 & -35.07 & 530 & 4.185 & -34.01 & 540 & 4.838 & -23.72 \\
\hline $\mathrm{E}$ & 0.989 & 294.4 & 6.518 & 175.9 & 505 & 2.8 & 566 & 4.272 & -34.46 & 564 & 4.136 & -36.55 & 563 & 4.070 & -37.56 & 563 & 4.070 & -37.56 \\
\hline $\mathrm{F}$ & 0.989 & 294.4 & 3.435 & 179.5 & 480 & 2.8 & 514 & 2.431 & -29.23 & 515 & 2.501 & -27.21 & 514 & 2.433 & -29.18 & 515 & 2.499 & -27.26 \\
\hline G & 0.989 & 294.4 & 9.689 & 178.7 & 500 & 2.8 & 591 & 6.479 & -33.13 & 586 & 6.133 & -36.71 & 584 & 5.998 & -38.10 & 504 & 0.762 & -92.14 \\
\hline $\mathrm{H}$ & 0.989 & 294.4 & 5.990 & 179.0 & 485 & 2.8 & 534 & 3.493 & -41.68 & 534 & 3.493 & -41.68 & 534 & 3.493 & -41.68 & 543 & 4.083 & -31.83 \\
\hline I & 0.989 & 294.4 & 8.632 & 177.8 & 483 & 2.8 & 567 & 5.948 & -31.10 & 567 & 5.948 & -31.10 & 565 & 5.814 & -32.65 & 567 & 5.944 & -31.14 \\
\hline $\mathrm{J}$ & 0.989 & 294.4 & 5.109 & 177.6 & 475 & 2.8 & 532 & 4.033 & -21.07 & 532 & 4.033 & -21.07 & 531 & 3.966 & -22.38 & 540 & 4.551 & -10.92 \\
\hline K & 0.989 & 294.4 & 8.985 & 177.3 & 474 & 2.8 & 568 & 6.639 & -26.11 & 568 & 6.639 & -26.11 & 568 & 6.639 & -26.11 & 572 & 6.899 & -23.22 \\
\hline
\end{tabular}




\subsubsection{Optimization of Incubation Time}

Three separate trials using three incubation jars selected for best performance were done to determine a suitable incubation time. Enough time should be allowed for the carbonate to fully react with the acid, but the jars should be sampled soon enough to limit any possibility of equilibration of $\mathrm{CO}_{2}$ with ambient conditions. For each trial, approximately $4-5 \mathrm{mg}$ of the 0.74 mass $\% \mathrm{NaHCO}_{3}$ mixture was spread onto each of three prebaked $\left(600^{\circ} \mathrm{C}\right.$ overnight $) 25 \mathrm{~mm}$ round quartz fiber filters. Each filter was placed onto a petri dish and sealed in an incubation jar. The background $\mathrm{CO}_{2}$ concentration was measured, and $3 \mathrm{~mL}$ of $1 \mathrm{M} \mathrm{HCl}$ was added to each jar, making sure to saturate the filter. The jar was gently swirled every few minutes to ensure complete release of $\mathrm{CO}_{2}$ bubbles from the aqueous phase. Measurements of $\mathrm{CO}_{2}$ were made at different time intervals, detailed in Figure 2 and Tables S1-S3 in Supplementary Materials.
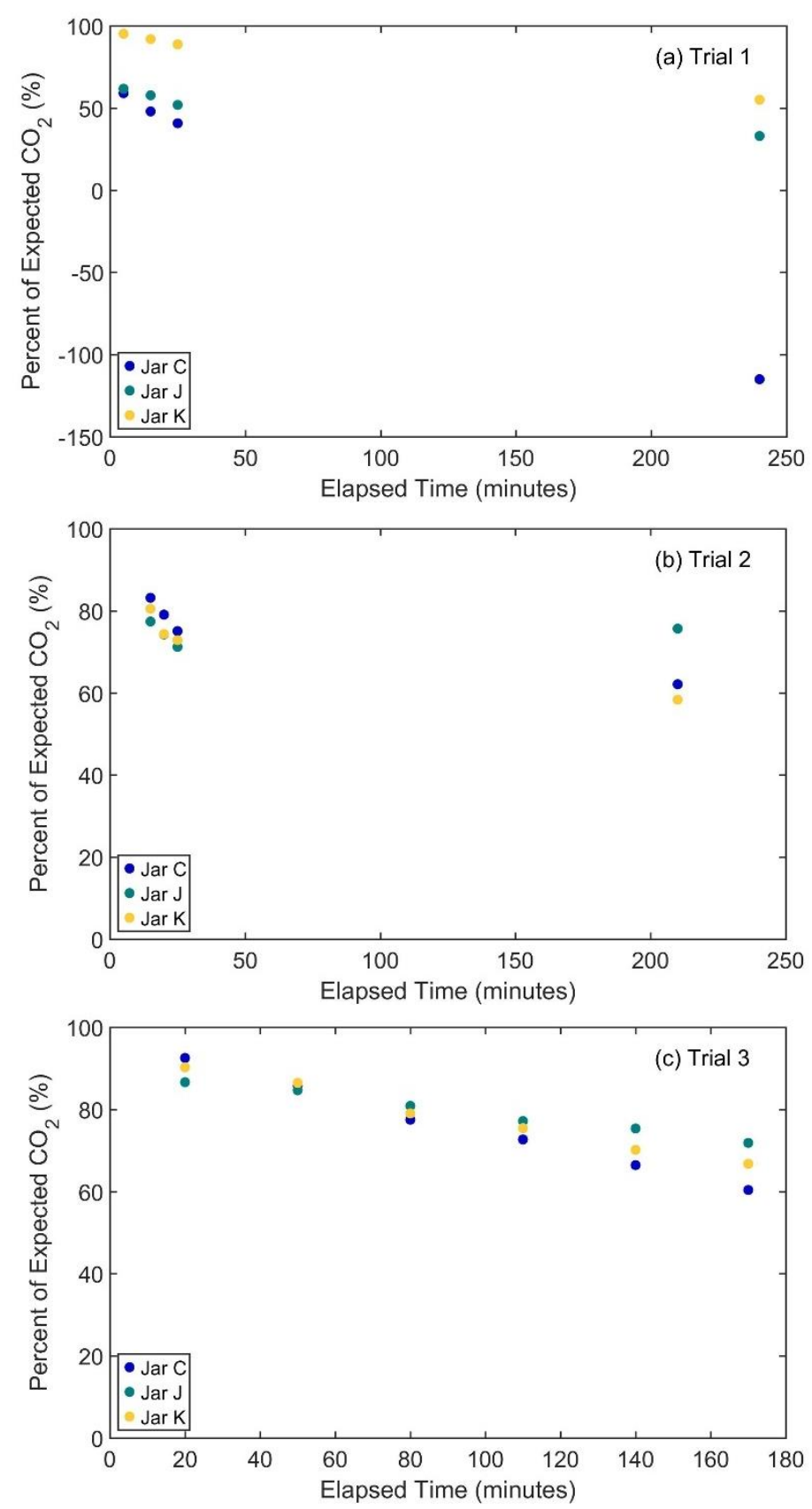

Figure 2. Plots of the three trials $(\mathbf{a}-\mathbf{c})$ performed to determine the incubation time needed for the carbonate present on the quartz filters to react with $1 \mathrm{M} \mathrm{HCl}$ and form $\mathrm{CO}_{2}$. In all three trials, the first measurement taken had the highest concentration of measured $\mathrm{CO}_{2}$. 


\subsection{Ambient Particulate Matter Sample Collection and Analysis}

Particulate matter samples were collected on the roof of the Life Sciences complex A (LSA) on the main campus of Arizona State University ( 33.4196 N,-111.9329 W, 357 m ASL). This urban location is surrounded by four major highways (Interstate 10, $3.7 \mathrm{~km}$ southwest; U.S. Route 60, $3.8 \mathrm{~km}$ to the south; Arizona State Route 101, $3.9 \mathrm{~km}$ to the east; and Arizona State Route 202, $1.8 \mathrm{~km}$ to the north). LSA is also approximately $6 \mathrm{~km}$ southeast of Phoenix Sky Harbor International Airport and $1.3 \mathrm{~km}$ south of Tempe Town Lake, a reservoir in the riverbed of the Salt River. Along with the ASU campus, Tempe also consists of residential and industrial areas. It is bordered by the cities of Phoenix to the west and Scottsdale to the north, and suburban areas to the east and south. As part of the Sonoran Desert, a significant contribution of mineral dust, including carbonate minerals, was expected in the local aerosol. Collection was performed using a Tisch high-volume aerosol sampler $\left(1.13 \mathrm{~m}^{3} / \mathrm{min}\right)$ equipped with a size-fractionating impaction stage to collect $\mathrm{PM}_{2.5}$ (particulate matter with an aerodynamic diameter of $2.5 \mu \mathrm{m}$ and below) and $\mathrm{PM}_{>2.5}$ (particulate matter with an aerodynamic diameter greater than $2.5 \mu \mathrm{m}$ ) onto quartz fiber filters. Additional samples were collected using a 6-stage multistage impactor TE 235 from Tisch Environmental (e.g., [15]). Both samplers collect filters on standard $8 \times 10$ quartz fiber filters $\left(\mathrm{PM}_{2.5}\right.$ and multistage impactor final stage) or on slotted filters $\left(\mathrm{PM}_{>2.5}\right.$ and multistage impactor). For the present analytical development study single stage $\mathrm{PM}_{>2.5}$ samples were collected in summer 2013 over $24-48 \mathrm{~h}$ while multistage samples were collected over one-week periods in January, April, June, and October 2013.

Large atmospheric particles are expected to contain a higher concentration of carbonate than small particles, since carbonate mineral dust is mechanically generated and is found in the coarse size mode [7-10]. Therefore, the $\mathrm{PM}_{>2.5}$ filters were used to test the reproducibility of this method. For the first trial, three $1.5 \mathrm{~cm}^{2}$ punches were taken from three different locations on the filter and were placed into a petri dish. The petri dish was placed into a jar, the jar was closed, the background $\mathrm{CO}_{2}$ concentration was measured, and $3 \mathrm{~mL}$ of $1 \mathrm{M} \mathrm{HCl}$ was added. The jar was gently swirled every few minutes to ensure complete release of $\mathrm{CO}_{2}$ gas from the aqueous phase. The $\mathrm{CO}_{2}$ concentration was measured after $20 \mathrm{~min}$. This procedure was repeated with the two other jars, using two $1.5 \mathrm{~cm}^{2}$ filter punches instead of three since the amount of $\mathrm{CO}_{2}$ formed in the first jar was high ( $235 \mathrm{ppmv}$ ). This procedure was repeated in additional trials using two $1.5 \mathrm{~cm}^{2}$ punches in each of the three incubation jars.

\section{Results and Discussion}

\subsection{Incubation Jar Seal Tests}

Before any measurements are made, the incubation jars need to be tested for leakage. A major concern in using containers for gas measurements is a leak resulting from a poor-fitting lid, a septum that is not properly sealed into the side of a jar, or an over-pierced septum. A visual inspection is not sufficient. Initially 11 containers were tested using a known mass of sodium bicarbonate to react with acid. Each jar was sampled four times over $2 \mathrm{~h}$ to determine which jars would result in the lowest percentage relative error from the expected amount of $\mathrm{CO}_{2}$ to be formed, which jars would maintain the internal $\mathrm{CO}_{2}$ pressure after multiple samplings, and which jars would result in the most consistent results. As seen in Table 1, the results varied widely among the jars: the relative error after $5 \mathrm{~min}$ of incubation ranged from $21-42 \%$ below the actual amount of bicarbonate present in the jar. Two jars did not maintain internal pressure over $2 \mathrm{~h}$, while five jars showed an increase of 4-10 ppmv of $\mathrm{CO}_{2}$. The $\mathrm{CO}_{2}$ in the remaining four jars remained consistent within 2 ppmv over $2 \mathrm{~h}$. Because of these irregularities, it was decided that two hours of incubation was likely too long for this type of experiment. In all jars, aside from jar $\mathrm{G}$, the measured amount of $\mathrm{CO}_{2}$ formed was consistent over 15 min of incubation. The three jars to be used in subsequent trials (jars $\mathrm{C}$, J and K) were chosen among those that exhibited lower relative errors and the most consistent results for the first three measurements. 


\subsection{Optimization of Incubation Time}

After choosing the jars to perform acidification experiments, an incubation time was determined. Enough time for the acid to react with carbonate was necessary to ensure that the method would be both accurate and reproducible. Additionally, since the bicarbonate standard was spread onto quartz sampling filters instead of being added directly to the petri dish, enough time was needed to ensure that the carbonate embedded in the filter could still react efficiently with the acid.

Three separate trials were performed using all three jars so that a variety of incubation times could be explored (Figure 2). In the first trial, three sample measurements were taken from each jar 5, 15 and $25 \mathrm{~min}$ after acid addition, and the fourth after four hours (Figure 2a). Between the first and third measurements, the concentration of $\mathrm{CO}_{2}$ decreased by up to $10 \mathrm{ppmv}$. It is apparent in these trials that jars $C$ and J performed poorly, with respective errors of $-41 \%$ and $-38 \%$ after 5 min of incubation, which became worse over time. Jar $\mathrm{K}$ had a low relative error in comparison to the other jars $(-5 \%)$, but it still lost $\mathrm{CO}_{2}$ over time. These issues may be attributed to a high $\mathrm{CO}_{2}$ concentration inside the jar (Table 1) before addition of acid, relative to the ambient concentration, which ranged from approximately $420-480 \mathrm{ppmv}$, depending on the activity in the room. The elevated $\mathrm{CO}_{2}$ pressures in the jars were likely caused by the experimenter's breath entering the jars just before they were closed, causing a gradient in $\mathrm{CO}_{2}$ partial pressures between the jar and atmosphere and accelerating the equilibration of $\mathrm{CO}_{2}$ with the ambient pressure. It was therefore important to ensure that the background $\mathrm{CO}_{2}$ pressure inside the jars was not elevated relative to the ambient $\mathrm{CO}_{2}$ pressure.

It was also noted during this trial that gas bubbles were still evolving from the filters about $10 \mathrm{~min}$ after acidification. It is possible that the bicarbonate standard becomes engrained in the filter and is slower to react with the acid than when it is loose in the petri dish. Therefore, an incubation time greater than $10 \mathrm{~min}$ should be used to ensure complete reaction of bicarbonate with acid and release of $\mathrm{CO}_{2}$ from the filter.

The second trial was used to test changes in $\mathrm{CO}_{2}$ measurements over short time intervals and to again see how the jars faired when sitting for several hours after bicarbonate acidification. Sodium bicarbonate standard was again spread onto a quartz filter and acidified in the jars, ensuring that the initial $\mathrm{CO}_{2}$ pressures inside of the jars were not excessively elevated relative to the ambient pressure. $\mathrm{CO}_{2}$ measurements were made 15, 20 and $25 \mathrm{~min}$ after acid addition, and again after $3.5 \mathrm{~h}$. The results are shown in Figure 2b. Between the first and third measurements of $\mathrm{CO}_{2}$ (at 15 and $25 \mathrm{~min}$ after $\mathrm{HCl}$ addition), the concentration of $\mathrm{CO}_{2}$ decreased by up to $6 \mathrm{ppmv}$. However, the relative error in the measurement of $\mathrm{CO}_{2}$ formed remained under $30 \%$ for all trials. Since the highest $\mathrm{CO}_{2}$ pressure was recorded at $15 \mathrm{~min}$, it can be assumed that the reaction is complete at this time point. After $3.5 \mathrm{~h}$, an additional $10 \mathrm{ppmv}$ of $\mathrm{CO}_{2}$ was lost from jars $\mathrm{C}$ and $\mathrm{K}$, further emphasizing that incubation over several hours is not ideal for this system.

In the final trial, incubation times from $20-170 \mathrm{~min}$ in $30 \mathrm{~min}$ increments were tested to determine if there were notable changes in measured $\mathrm{CO}_{2}$ within the first hour of acid addition, and to again assess if the jars could stay pressurized over several hours. As shown in Figure 2c, the highest $\mathrm{CO}_{2}$ pressure in each jar was measured $20 \mathrm{~min}$ after acid addition, with all relative errors of $\mathrm{CO}_{2}$ concentration within $15 \%$ of the expected concentration of $\mathrm{CO}_{2}$. Between each subsequent measurement, $1-5 \mathrm{ppmv}$ of $\mathrm{CO}_{2}$ was lost, and relative errors for jars $\mathrm{C}$, J and $\mathrm{K}$ increased by the end of the trial to $39.6 \%, 28.1 \%$ and $33.2 \%$, respectively, below the expected concentration of $\mathrm{CO}_{2}$. These results indicate that it would be reasonable to sample $\mathrm{CO}_{2}$ from the reaction of sodium bicarbonate and $\mathrm{HCl} 20 \mathrm{~min}$ after the addition of $\mathrm{HCl}$, since the reaction should be complete at this point and later sampling times indicate that $\mathrm{CO}_{2}$ is escaping the jars over time.

Based upon these optimization tests, jars $\mathrm{C}$, J and $\mathrm{K}$ were deemed adequate for use with atmospheric particulate matter samples. A $3 \mathrm{~mL}$ sample of $1 \mathrm{M} \mathrm{HCl}$ would be added to each jar, and the sample would react with the acid for $20 \mathrm{~min}$, at which point the measured concentration of $\mathrm{CO}_{2}$ was expected to be within $15 \%$ of the actual value. 


\subsection{Application to Atmospheric Particulate Matter Samples}

A sample of atmospheric particulate matter collected on the Arizona State University Tempe Campus from 27-30 March 2014 was analyzed. In the first trial, $4.5 \mathrm{~cm}^{2}$ of the filter was used, and the $\mathrm{CO}_{2}$ concentration measured $20 \mathrm{~min}$ after acid addition was $687 \mathrm{ppmv}$. Since the reproducibility tests using sodium bicarbonate resulted in measured $\mathrm{CO}_{2}$ concentrations near $500 \mathrm{ppmv}$, the amount of filter was reduced in successive trials to $3 \mathrm{~cm}^{2}$. The results are shown in Table 2 .

Table 2. Experiments performed aerosol particulate matter samples $\left(\mathrm{PM}_{>2.5}\right)$ to assess reproducibility on real samples.

\begin{tabular}{|c|c|c|c|c|c|c|c|c|c|}
\hline \multirow[b]{2}{*}{ Jar } & \multicolumn{6}{|c|}{ Incubation Conditions } & \multicolumn{3}{|c|}{20 Minute Incubation } \\
\hline & $\begin{array}{c}\text { Ambient } \\
\text { Pressure } \\
\text { (atm) }\end{array}$ & $\begin{array}{c}\text { Ambient } \\
\text { Temp. } \\
\text { (K) }\end{array}$ & $\begin{array}{l}\text { Filter } \\
\text { Area } \\
\left(\mathrm{cm}^{2}\right)\end{array}$ & $\begin{array}{l}\text { Container } \\
\text { Volume } \\
\text { (L) }\end{array}$ & $\begin{array}{c}\text { Bkgrnd. } \\
\mathrm{CO}_{2} \\
\text { (ppmv) }\end{array}$ & $\begin{array}{c}\text { HCl } \\
\text { Added } \\
\text { (L) }\end{array}$ & $\begin{array}{c}\mathrm{CO}_{2} \\
\text { Pressure } \\
\text { (ppmv) }\end{array}$ & $\begin{array}{c}\text { Moles } \mathrm{CO}_{2} \\
\text { Formed } \\
\left(\times 10^{-7} \mathrm{~mol}\right)\end{array}$ & $\begin{array}{c}\text { Carbonate } \\
\text { Carbon } \\
\text { Conc. } \\
\left(\mu \mathrm{gC} / \mathrm{cm}^{2}\right)\end{array}$ \\
\hline C & 0.9905 & 294.5 & 4.5 & 0.1771 & 452 & 0.003 & 4.6 & 4.6 & 4.6 \\
\hline $\mathrm{J}$ & 0.9905 & 294.4 & 3.0 & 0.1776 & 449 & 0.003 & 4.6 & 4.6 & 4.6 \\
\hline $\mathrm{K}$ & 0.9905 & 294.4 & 3.0 & 0.1773 & 448 & 0.003 & 4.6 & 4.6 & 4.6 \\
\hline C & 0.9946 & 294.4 & 3.0 & 0.1771 & 520 & 0.003 & 4.6 & 4.6 & 4.6 \\
\hline $\mathrm{J}$ & 0.9946 & 294.4 & 3.0 & 0.1776 & 435 & 0.003 & 4.6 & 4.6 & 4.6 \\
\hline $\mathrm{K}$ & 0.9946 & 294.4 & 3.0 & 0.1773 & 434 & 0.003 & 4.6 & 4.6 & 4.6 \\
\hline
\end{tabular}

The average concentration of CC on this aerosol sample was found to be $4.4 \mu \mathrm{gC} / \mathrm{cm}^{2}$, with a standard deviation of $0.3 \mu \mathrm{gC} / \mathrm{cm}^{2}$ and a range of 3.9-4.7 $\mu \mathrm{gC} / \mathrm{cm}^{2}$ (Table 3). This is equivalent to $86 \pm 6 \mathrm{ngC} / \mathrm{m}^{3}$ in $\mathrm{PM}_{>2.5}$ collected over a four-day sampling period. Other studies have found ranges of carbonate carbon in $\mathrm{PM}_{2.5}$ from less than $100 \mathrm{ngC} / \mathrm{m}^{3}$ to $420 \mathrm{ngC} / \mathrm{m}^{3}$ among 58 sites in the IMPROVE network [12]. $\mathrm{PM}_{1.5}$ was found to contain $100-300 \mathrm{ngC} / \mathrm{m}^{3}$ in a remote background location in central Sweden and 300-3000 ngC/ $/ \mathrm{m}^{3}$ in the Po Valley; CC was not detected in $\mathrm{PM}_{1.5}$ collected in a third rural site on the Great Hungarian Plateau [27]. Overall, there is good precision $\left(4.4 \pm 0.3 \mu \mathrm{gC} / \mathrm{cm}^{2}\right.$ for six replicates $)$ and reproducibility among the replicate $\mathrm{PM}_{>2.5}$ samples, showing that this method could be promising as a way to measure CC on aerosol filters with low or inhomogeneous sample loads.

Table 3. Results of carbonate analysis in size-segregated aerosol samples.

\begin{tabular}{ccccccc}
\hline Sample Description & $\begin{array}{c}\text { Filter Area } \\
\left.\mathbf{( c m}^{2}\right)\end{array}$ & $\begin{array}{c}\text { Carbonate } \\
\text { Carbon } \\
\text { Conc. } \\
\left(\mu \mathbf{g C} / \mathbf{c m}^{2}\right)\end{array}$ & $\begin{array}{c}\text { Std. Dev. } \\
\left(\mu \mathrm{gC} / \mathbf{c m}^{2}\right)\end{array}$ & $\begin{array}{c}\text { Number Of } \\
\text { Replicates }\end{array}$ & $\begin{array}{c}\text { Carbonate: } \\
\text { Total } \\
\text { Carbon (\%) }\end{array}$ & $\begin{array}{c}\text { Uncertainty } \\
(\%)\end{array}$ \\
\hline $\mathrm{PM}_{>2.5}$ & $*$ & 4.4 & 0.3 & 6 & $*$ & $* *$ \\
January $\mathrm{PM}_{>7.2}$ & 3 & 3.8 & 0.3 & 3 & 4.4 & 0.4 \\
January $\mathrm{PM}_{3-7.2}$ & 3 & 3.4 & 0.2 & 3 & 7.4 & 0.7 \\
January $\mathrm{PM}_{1.5-3}$ & 3 & 1.7 & 0.3 & 4 & 5.2 & 0.9 \\
January $\mathrm{PM}_{0.95-1.5}$ & 3 & 1.0 & 0.2 & 4 & 2.2 & 0.4 \\
January $\mathrm{PM}_{0.49-0.95}$ & 4.5 & 0.65 & 0.02 & 3 & 2.3 & 0.1 \\
January $\mathrm{PM}_{<0.49}$ & 6 & 1.2 & 0.3 & 3 & 1.1 & 0.2 \\
April $\mathrm{PM}_{3-7.2}$ & 4.5 & 2.9 & 0.3 & 3 & 10 & 1 \\
April $\mathrm{PM}_{<0.49}$ & 6 & 3.7 & 0.2 & 3 & 5.5 & 0.4 \\
June $\mathrm{PM}_{<0.49}$ & 6 & 3.6 & 0.5 & 3 & 5.1 & 0.8 \\
October $\mathrm{PM}_{>7.2}$ & 4.5 & 3.01 & 0.06 & 3 & 5.7 & 0.3 \\
October $\mathrm{PM}_{3-7.2}$ & 4.5 & 3.0 & 0.1 & 3 & 7.1 & 0.5 \\
October $\mathrm{PM}_{<0.49}$ & 6 & 1.90 & 0.09 & 3 & 2.6 & 0.2 \\
\hline
\end{tabular}

* $4.5 \mathrm{~cm}^{2}$ were used in one replicate, $3 \mathrm{~cm}^{2}$ were used in five replicates. ${ }^{* *}$ Total Carbon was not measured.

Once this method was successfully tested on an atmospheric particulate matter sample, twelve sizesegregated filters collected at the same site were also analyzed for CC. Table 3 summarizes the results of these analyses. The amount of carbonate collected on each filter varied from $0.65 \pm 0.02 \mu \mathrm{g} / \mathrm{cm}^{2}$ to $3.8 \pm 0.3 \mu \mathrm{g} / \mathrm{cm}^{2}$, and the percentage of total carbon that was carbonate ranged from $1.1 \pm 0.2 \%$ 
to $10 \pm 1 \%$. The amount of carbonate mainly varied based upon the size fraction, with particles in the size range $3 \mu \mathrm{m}<\mathrm{dp}<7.2 \mu \mathrm{m}$ containing the highest percent of carbonate relative to total carbon. These values are similar to a previous study which determined that coarse PM (PM $\left.\mathrm{PM}_{10.5}\right)$ in Phoenix contains an average of $9 \%$ CC by thermal optical analysis of acidified filters [28]. The standard deviation of replicate measurements ranged from $2-22 \%$ of the average carbonate concentration, with a median of $8 \%$, showing again that this method of quantifying CC is reproducible and results in good measurement precision.

\subsection{Implications for Generalized Application to Atmospheric Studies}

In order to apply this carbonate quantification method to other particulate matter samples, several considerations must be made in terms of sample collection, including the filter size, sampler type and sampling time. The smallest amount of $\mathrm{CO}_{2}$ liberated from a particulate matter sample will be used as a lower limit of detection: the particle size fraction $0.49 \mu \mathrm{m}<\mathrm{dp}<0.95 \mu \mathrm{m}$ collected in January yielded an average of 34 ppmv of $\mathrm{CO}_{2}$ upon acidification. A petri dish placed into an incubation jar has an area of $24 \mathrm{~cm}^{2}$; this is the maximum area of filter that can be tested at a time. Using Equations 1-14 (SI) and the experimental parameters for this sample, a filter of size $24 \mathrm{~cm}^{2}$ that liberates $34 \mathrm{ppmv}$ of $\mathrm{CO}_{2}$ upon acidification would contain $0.12 \mu \mathrm{gC} / \mathrm{cm}^{2}$ of carbonate. Assuming that sample collection is taking place in Tempe, it is reasonable to presume that TC in Tempe will contain somewhere between $1-10 \%$ CC; therefore, the TC collected on this filter would range from $1.2-12 \mu \mathrm{gC} / \mathrm{cm}^{2}$. The average concentration of TC in $\mathrm{PM}_{2.5}$ in Tempe is $4.3 \mu \mathrm{gC} / \mathrm{m}^{3}$ [4]. Using this information, if a high-volume sampler with sampling velocity of $1.13 \mathrm{~m}^{3} / \mathrm{min}$ is used for collection, then enough particulate matter will be collected for carbonate analysis between $6 \mathrm{~min}$ (if CC is 10\% of TC) and $60 \mathrm{~min}$ (if CC is $1 \%$ of TC) of sampling time. Carbonate can therefore be measured even when the sampling time is relatively short, provided that enough filter area is available for triplicate measurements. In locations other than Tempe, with lower carbonate concentrations, measurements might still be achieved by using longer sampling times and larger filter areas (see Supplementary Materials).

The sampling time needed to measure CC concentration does, however, increase if a low-volume particulate matter sampler is used. As an example, if $\mathrm{PM}_{2.5}$ is collected using a low-volume sampler with a sampling velocity of $2.3 \mathrm{~m}^{3} / \mathrm{h}(38 \mathrm{LPM})$ and a filter deposition area of $12.6 \mathrm{~cm}^{2}$. If the entire filter is used to quantify $\mathrm{CC}$, and $34 \mathrm{ppmv}$ of $\mathrm{CO}_{2}$ is again liberated from the filter upon acidification, the filter will need to contain $0.23 \mu \mathrm{gC} / \mathrm{cm}^{2}$ of carbonate. Again, assuming that $1-10 \%$ of TC in Tempe is carbonate, the TC loaded onto the filter would range from $2.3-23 \mu \mathrm{gC} / \mathrm{cm}^{2}$. Using this low-volume sampler, enough particulate matter will be collected for carbonate analysis between $3 \mathrm{~h}$ (if CC is $10 \%$ of TC) and $30 \mathrm{~h}$ (if CC is 1\% of TC) of sampling time. This, again, assumes that the entire sample will be used in analysis. Ideally, triplicate measurements will be made, increasing the required sampling time threefold.

\section{Conclusions}

A new method to quantify the carbonate carbon (CC) in atmospheric particulate matter samples has been investigated. In this approach, the amount of $\mathrm{CO}_{2}$ formed when a sample in a sealed jar is acidified is measured via infrared absorbance, and the moles of $\mathrm{CO}_{2}$ formed are equated to the moles of carbonate present in the sample. The analysis of a known amount of sodium bicarbonate applied to a filter resulted in a relative error within $15 \%$ of the known mass of bicarbonate when measured 20 min after acidification. $\mathrm{A} \mathrm{PM}_{>2.5}$ aerosol filter collected via cascade impaction on a high-volume aerosol sampler yielded good precision, with a CC concentration of $4.4 \pm 0.3 \mu \mathrm{gC} / \mathrm{cm}^{2}$ for six replicates. Twelve filters containing PM in various size fractions collected in Tempe, AZ were also analyzed in triplicate, with standard deviations ranging from $2-22 \%$ of the average carbonate concentration. The high precision, accuracy and reproducibility of this method of CC measurement makes it a good alternative to existing quantification methods. 
Supplementary Materials: The following are available online at http://www.mdpi.com/2073-4433/11/6/661/s1, overview of calculations and Tables S1-S3.

Author Contributions: Conceptualization, D.C.N., H.E.H. and P.H.; methodology, D.C.N. and P.H.; writing —original draft preparation, D.C.N.; writing—review and editing, D.C.N., H.E.H. and P.H. All authors have read and agreed to the published version of the manuscript.

Funding: This article was developed under Assistance Agreement No. FP-91780301-0 awarded by the U.S. Environmental Protection Agency to Denise Napolitano. It has not been formally reviewed by EPA. The views expressed in this document are solely those of the authors and do not necessarily reflect those of the Agency. EPA does not endorse any products or commercial services mentioned in this publication. Partial support for this work was provided by the National Science Foundation under grant number DEB-1832016, Central Arizona-Phoenix Long-Term Ecological Research Program (CAP LTER).

Conflicts of Interest: The authors declare no conflict of interest. The funders had no role in the design of the study; in the collection, analyses, or interpretation of data; in the writing of the manuscript, or in the decision to publish the results.

\section{References}

1. Ramadan, Z.; Song, X.H.; Hopke, P.K. Identification of sources of Phoenix aerosol by positive matrix factorization. J. Air Waste Manag. Assoc. 1995, 50, 1308-1320. [CrossRef] [PubMed]

2. Lewis, C.W.; Norris, G.A.; Conner, T.L.; Henry, R.C. Source Apportionment of Phoenix PM2.5 Aerosol with the Unmix Receptor Model. J. Air Waste Manag. Assoc. 2003, 53, 325-338. [CrossRef] [PubMed]

3. Brown, S.G.; Frankel, A.; Raffuse, S.M.; Roberts, P.T.; Hafner, H.R.; Anderson, D.J. Source apportionment of fine particulate matter in Phoenix, AZ, using positive matrix factorization. J. Air Waste Manag. Assoc. 2007, 57, 741-752. [CrossRef]

4. Upadhyay, N.; Clements, A.; Fraser, M.; Herckes, P. Chemical speciation of PM2.5 and PM10 in South Phoenix, AZ, USA. J. Air Waste Manag. Assoc. 2011, 61, 302-310. [CrossRef]

5. Cahill, T.M. Annual cycle of size-resolved organic aerosol characterization in an urbanized desert environment. Atmos. Environ. 2013, 71, 226-233. [CrossRef]

6. Manoli, E.; Voutsa, D.; Samara, C. Chemical characterization and source identification/apportionment of fine and coarse air particles in Thessaloniki, Greece. Atmos. Environ. 2002, 36, 949-961. [CrossRef]

7. Mardi, A.H.; Khaghani, A.; MacDonald, A.B.; Nguyen, P.; Karimi, N.; Heidary, P.; Karimi, N.; Saemian, P.; Sehatkashani, S.; Tajrishy, M.; et al. The Lake Urmia environmental disaster in Iran: A look at aerosol pollution. Sci. Tot. Environ. 2018, 633, 42-49. [CrossRef]

8. Garbaras, A.; Rimselyte, K.; Kvietkus, K.; Remeikis, V. $\delta 13 \mathrm{C}$ values in size segregated atmospheric carbonaceous aerosols at a rural site in Lithuania. Lith. J. Phys. 2009, 49, 229-236. [CrossRef]

9. López-Veneroni, D. The stable carbon isotope composition of PM2.5 and PM10 in Mexico City Metropolitan Area air. Atmos. Environ. 2009, 43, 4491-4502. [CrossRef]

10. Masalaite, A.; Remeikis, V.; Garbaras, A.; Dudoitis, V.; Ulevicius, V.; Ceburnis, D. Elucidating carbonaceous aerosol sources by the stable carbon $813 \mathrm{CTC}$ ratio in size-segregated particles. Atmos. Res. 2015, 158-159, 1-12. [CrossRef]

11. Chow, J.C.; Watson, J.G.; Crow, D.; Lowenthal, D.H.; Merrifield, T. Comparison of IMPROVE and NIOSH Carbon Measurements. Aerosol. Sci. Technol. 2001, 34, 23-34. [CrossRef]

12. Chow, J.C.; Watson, J.G. PM2.5 carbonate concentrations at regionally representative Interagency Monitoring of Protected Visual Environment sites. J. Geophys. Res. Atmos. 2002, 107, ICC 6-1-ICC 6-9. [CrossRef]

13. Cao, J.J.; Lee, S.C.; Zhang, X.Y.; Chow, J.C.; An, Z.S.; Ho, K.F.; Watson, J.G.; Fung, K.; Wang, Y.Q.; Shen, Z.X. Characterization of airborne carbonate over a site near Asian dust source regions during spring 2002 and its climatic and environmental significance. J. Geophys. Res. Atmos. 2005, 110, 1-8. [CrossRef]

14. Birch, M.E.; Cary, R.A. Elemental Carbon-Based Method for Monitoring Occupational Exposures to Particulate Diesel Exhaust. Aerosol. Sci. Technol. 1996, 25, 221-241. [CrossRef]

15. Cachier, H.; Bremond, M.; Buat-Menard, P. Determination of atmospheric soot carbon with a simple thermal method. Tellus 1989, 41B, 379-390. [CrossRef]

16. Herckes, P.; Engling, G.; Kreidenweis, S.M.; Collett, J.L. Particle Size Distributions of Organic Aerosol Constituents during the 2002 Yosemite Aerosol Characterization Study. Environ. Sci. Technol. 2006, 40, 4554-4562. [CrossRef] 
17. Sunset Laboratory Inc., Retrieved. 2018. Available online: www.sunlab.com/ (accessed on 29 May 2018).

18. Webb, T.L.; Kruger, J.E. Carbonates in Differential Thermal Analysis; MacKenzie, R.C., Ed.; Academic Press: New York, NY, USA, 1970; pp. 303-341.

19. Criado, J.M.; Ortega, A. A study of the influence of particle size on the thermal decomposition of $\mathrm{CaCO}_{3}$ by means of constant rate thermal analysis. Thermochim. Acta 1992, 195, 163-167. [CrossRef]

20. Cary, B.; (Sunset Laboratory Inc., Tigard, OR, USA). Personal communication, 2017.

21. McCrea, J.M. On the Isotopic Chemistry of Carbonates and a Paleotemperature Scale. J. Chem. Phys. 1950, 18, 849-857. [CrossRef]

22. Chen, B.; Jie, D.; Shi, M.; Gao, P.; Shen, Z.; Uchida, M.; Zhou, L.; Liu, K.; Kitagawa, H. Characteristics of 14C and 13C of carbonate aerosols in dust storm events in China. Atmos. Res. 2015, 164-165, 297-303. [CrossRef]

23. Chen, B.; Cui, X.; Wang, Y. Regional prediction of carbon isotopes in soil carbonates for Asian dust source tracer. Atmos. Environ. 2016, 142, 1-8. [CrossRef]

24. Clarke, A.G.; Karani, G.N. Characterization of the Carbonate Content of Atmospheric Aerosols. J. Atmos. Chem. 1992, 14, 119-128. [CrossRef]

25. Noonan, K. Element Use and Acquisition Strategies in Biological Soil Crusts. Ph.D. Thesis, Arizona State University, Tempe, AZ, USA, 2012.

26. Hamilton, G.A. Soot Black Carbon Dynamics in Arid/Urban Ecosystems. Ph.D. Thesis, Arizona State University, Tempe, AZ, USA, 2013.

27. Zappoli, S.; Andracchio, A.; Fuzzi, S.; Facchini, M.C.; Gelencsér, A.; Kiss, G.; Krivácsy, Z.; Molnár, Á.; Mészáros, E.; Hansson, H.-C.; et al. Inorganic, organic and macromolecular components of fine aerosol in different areas of Europe in relation to their water solubility. Atmos. Environ. 1999, 33, 2733-2743. [CrossRef]

28. Turner, J.R.; Brown, S.G.; Minor, H.A. EPA's Pilot Study: Coarse PM Monitoring Program Results. U.S. Environmental Protection Agency Office of Air Quality Planning and Standards. 2015. Available online: https:/www3.epa.gov/ttn/amtic/files/pm10pilot/PMc_ReportEPA454R-15-001.pdf (accessed on 15 June 2020).

(C) 2020 by the authors. Licensee MDPI, Basel, Switzerland. This article is an open access article distributed under the terms and conditions of the Creative Commons Attribution (CC BY) license (http://creativecommons.org/licenses/by/4.0/). 